\title{
HUBUNGAN TIPE DASAR PERAIRAN DENGAN DISTRIBUSI IKAN DEMERSAL DI PERAIRAN PANGKAJENE SULAWESI SELATAN 2011
}

\section{(THE RELATION BETWEEN SEA BOTTOM TYPE AND DEMERSAL FISH IN PANGKAJENE WATERS SOUTH SULAWESI 2011)}

\author{
Hidayanto Akbar, ${ }^{1,2}$, Sri Pujiyati ${ }^{2}$, M. Natsir ${ }^{3}$ \\ ${ }^{1}$ Corresponding author \\ 2Departemen Ilmu dan Teknologi Kelautan \\ Fakultas Perikanan dan Ilmu Kelautan, Institut Pertanian Bogor \\ 3Pusat Penelitian Pengelolaan Perikanan dan Konservasi Sumberdaya Ikan \\ Kementerian Kelautan dan Perikanan \\ E-mail: hidayantoakbar@ymail
}

\begin{abstract}
The bottom on benthic substrate type of waters affect the distribution of demersal fish species. Type of the substrate in waters Pangkajene South Sulawesi dominated by muddy sand. The highest distribution of demersal fish was found in the depth of $10.45 \mathrm{~m}$ until $15.25 \mathrm{~m}$ with substrate muddy sand, demersal fish was the family of kakap or jenaha (Lutjanidae). Fish demersal in waters Pangkajene more influenced by the depth of waters than type of the substrate on the waters.
\end{abstract}

Keywords: Substrate type, demersal fish, Pangkajene

\section{ABSTRAK}

Tipe substrat dasar perairan berpengaruh terhadap sebaran jenis ikan demersal. Tipe substrat di Perairan Pangkajene Sulawesi Selatan didominasi oleh pasir berlumpur. Distribusi ikan demersal tertinggi berada di kedalaman $10.45 \mathrm{~m}$ sampai $15.25 \mathrm{~m}$ menyukai substrat pasir berlumpur, ikan demersal tersebut merupakan famili dari kapan atau jenaha (Lutjanidae). Ikan demersal di Perairan Pangkajene lebih dipengaruhi oleh kedalaman perairan dibandingkan oleh tipe substrat pada perairan tersebut.

Kata kunci: Tipe substrat, ikan demersal, Pangkajene

\section{PENDAHULUAN}

Pengetahuan mengenai sumberdaya laut merupakan hal penting, baik sumberdaya biotik dan abiotik. Setiap sumberdaya laut tersusun dalam suatu ekosistem dengan karakteristik interaksi tertentu. Interaksi antar ekosistem ini membentuk suatu keseimbangan lingkungan laut. Keterkaitan antar interaksi dari ekosistem laut dapat saling mempengaruhi, seperti interaksi ikan demersal (ikan dasar) terhadap sedimen (dasar perairan).

Substrat dasar perairan memliki peranan sebagai penyimpan unsur hara (bahan anorganik) yang berasal dari laut dan yang berasal dari daratan melalui berbagai proses. Bahan anorganik yang berada di substrat dimanfaatkan oleh mikrofauna sebagai pengurai menjadi bahan organik yang kemudian digunakan sebagai bahan makanan bagi organisme lain. Ikan demersal sebagai makrofauna juga sangat bergantung pada substrat dasar perairan, hal ini disebabkan karena ikan demersal banyak mengambil makanan di substrat dasar perairan. Makanan ikan demersal berupa bentos, moluska maupun biota kecil lainnya yang berada pada substrat dasar perairan (Pujiyati, 2008). Substrat dasar juga berperan sebagai tempat tinggal bagi ikan demersal.

Beberapa ikan demersal lebih menyukai terumbu karang sebagai tempat hidupnya dan mencari makan, namun ada beberapa ikan demersal yang lebih menyukai substrat pasir atau lumpur sebagai tempat hidupnya dan mencari makan. Pada substrat pasir atau lumpur terdapat berbagai jenis bentos yang hidup di dalamnya (Nugraheni, 2011).

Menurut Siswanto (2008), metode hidroakustik merupakan suatu metode untuk memperoleh keterangan-keterangan tentang objek dan peristiwa-peristiwa di dalam air dengan cara memancarkan gelombang suara dan mempelajari echo yang dipantulkan. Metode hidroakustik 
dapat memberikan informasi sebaran ikan demersal dan substrat perairan serta dapat menjelaskan hubungan antara keduanya.

Beberapa penelitian yang telah dilakukan mengenai hubungan ikan demersal dan substrat perairan dengan metode hidroakustik telah dilakukan. Pujiyati (2008) menyatakan bahwa di Perairan Laut Jawa, faktor-faktor abiotik seperti jenis substrat dasar peraian dan kondisi oseanografis sangat berpengaruh terhadap distribusi komunitas ikan-ikan demersal. Nugraheni (2011) menunjukkan hasil bahwa ikan demersal lebih dipengaruhi oleh makrozoobentos dibandingkan dengan substrat dasar perairan.

Penelitian ini bertujuan untuk menunjukkan hubungan dari tipe dasar perairan (E1 dan E2) terhadap distribusi ikan demersal (Sv ikan) di Perairan Pangkajene Sulawesi Selatan tahun 2011 dengan menggunakan metode hidroakustik.

\section{METODOLOGI}

\subsection{Pengambilan Data}

Penelitian ini menggunakan data hasil survei Balai Penelitian Perikanan Laut (BPPL) Jakarta, yang dilaksanakan pada tanggal 8-12 Oktober 2011 dengan pengambilan lokasi di Perairan Pangkajene Sulawesi Selatan yaitu pada posisi 4'46'9" LS dan $119^{\circ} 28^{\prime} 36^{\prime}$ " BT sampai $5^{\circ} 1^{\prime} 41^{\prime \prime}$ LS dan $119^{\circ} 21^{\prime} 13^{\prime \prime}$ BT (Gambar 1). Perekaman data akustik dilakukan sepanjang lintasan (track) secara kontinu sehingga diperoleh sebanyak 64 lintasan. Pengambilan data akustik menggunakan kapal nelayan setempat (15GT) dan dengan menggunakan perangkat BioSonics dengan tipe transducer split beam dengan setting frekuensi $201 \mathrm{KHz}$, pulse duration $0.5 \mathrm{~m} / \mathrm{s}$, sound speed $1542.43 \mathrm{~m} / \mathrm{s}$, dan absoption koeffisien $0.08472 \mathrm{~dB} / \mathrm{Km}$. Data ikan demersal diperoleh dari hasil tangkapan nelayan setempat berupa jenis ikan (species) dan hasil tangkapan (kg) selama 7 bulan (bulan April 2011 hingga Oktober 2011).

\subsection{Pengolahan Data}

Data akustik diolah dengan menggunkan perangkat lunak Echoview 4.0. Hambur balik pertama atau E1 yang menggambarkan kekasaran diolah dengan menggunakan minimum threshold $-50 \mathrm{~dB}$ dan maksimum threshold $0 \mathrm{~dB}$ serta ketebalan integrasi sebesar 0.38561 meter. Hambur balik kedua atau E2 yang menggambarkan kekerasan diolah dengan menggunakan minimum threshold $-70 \mathrm{~dB}$ dan maksimum threshold 0 dB. Hambur balik ikan demersal diolah dengan menggunakan minimum threshold $-80 \mathrm{~dB}$ dan maksimum threshold $-34 \mathrm{~dB}$ serta ketebalan integrasi sebesar 5 meter. Nilai ESDU (Elementary Distance Sampling Unit) sebesar 300 ping dan range grid sebesar 58 meter.

Hambur balik substrat perairan (E1 dan E2) dan ikan demersal diklasifikasi berdasarkan selang kelas kedalaman yang dibagi menjadi 11 kelas kedalaman dengan interval kelas 4.8 meter. Analisa hubungan E2 terhadap E1 dengan menggunakan regresi linear sederhana. Analisa hubungan substrat perairan terhadap distribusi ikan demersal menggunakan analisa komponen utama (AKU).

\section{PEMBAHASAN}

\subsection{Volume Backscatter Dasar Perairan First Bottom (E1) dan Seccond Bottom (E2)}

Perairan Pangkajene memiliki kedalaman yang dangkal dengan kedalaman berkisar antara $5.73 \mathrm{~m}$ sampai $58.40 \mathrm{~m}$, dengan rata-rata kedalaman $35.02 \mathrm{~m}$. Nilai rata-rata E1 Perairan Pangkajene -25.83 dB mengalami penurunan semakin bertambahnya kedalaman. Nilai E1 berbeda pada setiap lintasan. Sebaran E1 secara vertikal dan horizontal dapat dilihat pada Gambar 2 . Tipe substrat dasar di Perairan Pangkajene mengacu pada hasil penelitian yang dilakukan di Perairan Sumur (Allo, 2008). Tipe Substrat di Perairan Pangkajene didominsai oleh tipe substrat pasir berlumpur terdapat pada 44 lintasan (Tabel 1).

Nilai rata-rata E2 dari Perairan Pangkajene -58.35 dB. E2 bervariasi pada setiap kedalaman dan setiap lintasan (Gambar 3). E1 dan E2 diklasifikasikan berdasarkan selang kelas kedalaman sehingga diperoleh tipe substrat pada masing-masing selang kelas (Tabel 2). Substrat akan semakin lunak dengan bertambahnya kedalaman, ditunjukkan oleh nilai E1 semakin menurun. 

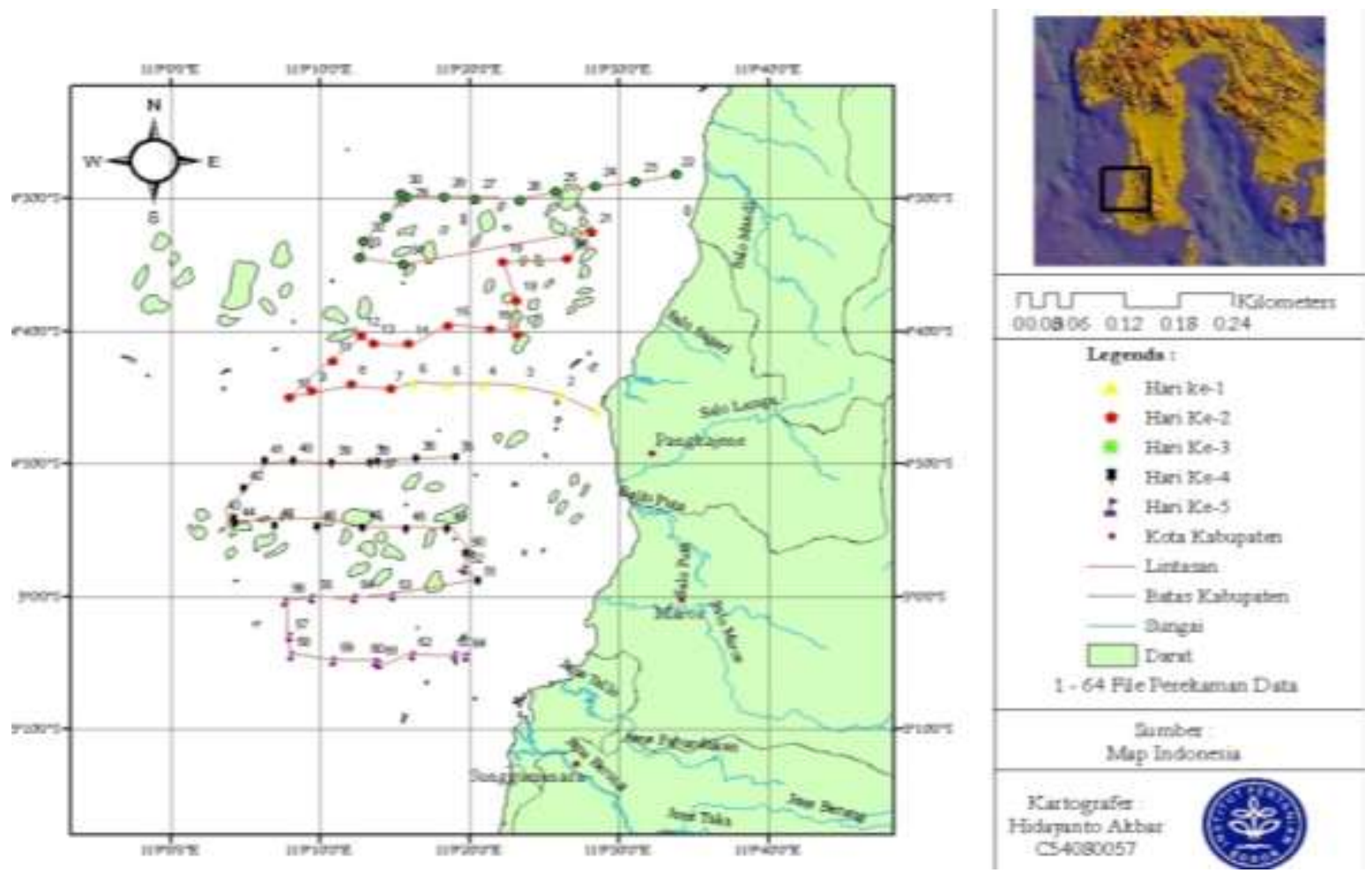

Gambar 1. Lokasi Penelitian

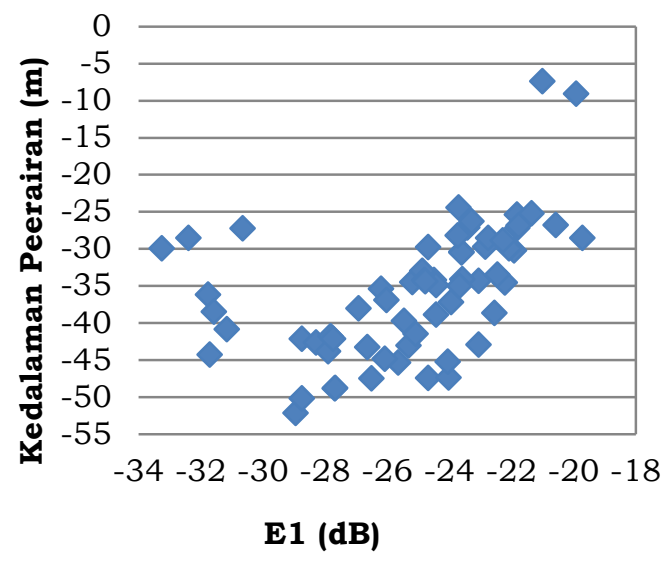

a.

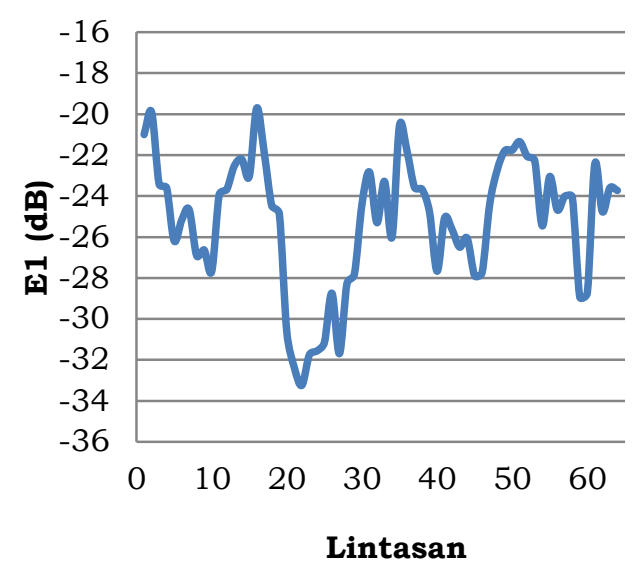

b.

Gambar 2. a. Sebaran vertikal E1; b. Sebaran horizontal E1

Tabel 1. Klasifikasi tipe substrat berdasarkan E1 dengan keberadaan pada lintasan

\begin{tabular}{ccc}
\hline E1 $(\mathrm{dB})$ & Tipe Substrat & Lintasan \\
\hline-19.71 sampai -21.01 & Pasir & $1,2,16$ dan 35 \\
-21.35 sampai -26.91 & Pasir berlumpur & $3-9,11-15,17-19,30-34,36-$ \\
& & $39,41-44,47-58$, dan 60-64 \\
-27.67 sampai -28.94 & Lumpur berpasir & $10,26,28,29,40,45,46,59$ \\
& & dan 60 \\
-30.64 sampai -33.24 & Lumpur & $20-25$ dan 27 \\
\hline
\end{tabular}


Substrat yang dominan di Perairan Pangkajene terhadap perubahan kedalaman adalah pasir berlumpur, sedangkan tipe substrat lumpur tidak terdapat di Perairan Pangkajene terhadap perubahan kedalaman. Pujiyati (2008) menyatakan bahwa backscattering dipengaruhi oleh ukuran partikel, selain itu dapat juga dipengaruhi oleh faktor porositas, kandungan zat organik, dan biota yang terkandung didalam substrat tersebut.

\subsection{Volume Backscattering Dasar Perairan}

Hubungan antara nilai hambur balik E1 dan E2 dapat ditunjukkan dengan analisis regresi dan korelasi. Analisis regresi dan korelasi menunjukkan bahwa peningkatan hambur balik E2 terhadap hambur balik E1 membentuk garis linear positif dengan persamaan E2 $=0.85 \mathrm{E} 1-38.38$ dengan koefisien determinasi 0.5 dan nilai korelasi 0.71. Peningkatan kekasaran substrat (nilai E1 sebesar satu satuan dB) akan meningkatkan kekerasan substrat tersebut (nilai E2 meningkat sebesar $0.85 \mathrm{~dB})$.

Tipe substrat dapat diterangkan dengan menggunakan hubungan antara E2 (hardness/kekerasan) dan E1 (roughness/kekasaran) (Gambar 4), semakin besar kedua nilai tersebut maka jenis substrat suatu perairan berupa substrat keras dan kasar. E2 menunjukkan kekerasan dari keras (kanan) hingga lunak (kiri), sedangkan E1 menunjukkan kekasaran dari kasar (atas) hingga halus (bawah). Tipe substrat di Perairan Pangkajene adalah keras dan kasar, dikarenakan lebih dominan berada pada 24 lintasan dari 64 lintasan.

Tipe substrat diplotkan pada masing-masing lintasan sehingga dapat terlihat penyebaran tipe substrat pada lokasi penelitian (Gambar 5). Substrat pasir dan pasir berlumpur wilayah penyebarannya berada di daerah pantai. Allo (2008) menyatakan bahwa daerah pantai memiliki substrat pasir dan pasir berlumpur disebabkan memiliki kedalaman yang dangkal serta dipengaruhi oleh faktor pergerakan arus dan gelombang yang kuat. Adanya pengaruh arus dan gelombang dapat mengakibatkan fraksi lumpur dan lumpur berpasir tidak dapat mengendap di sepanjang pantai, akibatnya pada daerah ini hampir sebagian besar didominasi oleh kedua tipe substrat pasir dan pasir berlumpur. Menjauhi pantai substrat yang ditemukan adalah lumpur berpasir. Substrat lumpur berada di wilayah bagian utara lokasi penelitian, dikarenakan pada wilayah tersebut memiliki kedalaman yang dalam.

\subsection{Sebaran Data Akustik untuk Ikan Demersal}

Nilai rata-rata $\mathrm{Sv}$ ikan di Perairan Pangkajene $-63.36 \mathrm{~dB}$. Terjadi variasi nilai hambur balik ikan demersal terhadap kedalaman dan pada setiap lintasan (Gambar 6).

Tabel 2. Rata-rata E1dan E2 serta tipe substrat pada selang kelas kedalaman

\begin{tabular}{cccc}
\hline $\begin{array}{c}\text { Selang Kelas Kedalaman } \\
\text { Dasar Perairan (meter) }\end{array}$ & E1 (dB) & E2 (dB) & Tipe Substrat \\
\hline $5.65-10.45$ & -20.39 & -58.16 & Pasir \\
$10.45-15.25$ & -21.29 & -57.50 & Pasir berlumpur \\
$15.25-20.05$ & -22.43 & -56.58 & Pasir berlumpur \\
$20.05-24.48$ & -22.15 & -56.18 & Pasir berlumpur \\
$24.48-29.65$ & -22.88 & -56.70 & Pasir berlumpur \\
$29.65-34.45$ & -23.94 & -58.98 & Pasir berlumpur \\
$34.45-39.25$ & -25.42 & -59.42 & Pasir berlumpur \\
$39.25-44.05$ & -26.15 & -59.33 & Pasir berlumpur \\
$44.05-48.85$ & -26.9 & -60.35 & Pasir berlumpur \\
$48.85-53.65$ & -28.36 & -57.59 & Lumpur berpasir \\
$53.65-58.45$ & -28.61 & - & Lumpur berpasir \\
\hline
\end{tabular}


Semakin besar nilai Sv ikan maka pengelompokkan target semakin besar, semakin kecil nilai Sv ikan yang diperoleh maka pengelompokkan target yang terdeteksi akan semakin sedikit (Burdah, 2008). Sv ikan mengalami penurunan dengan beratambahnya kedalaman (Tabel 3). Distribusi ikan demersal terbesar di Perairan Pangkajene berada pada kedalaman $10.45 \mathrm{~m}$ sampai 15.25 $\mathrm{m}$, hal ini dikarenakan nilai hambur balik yang tinggi dan lebih menyukai tipe substrat pasir berlumpur. Distribusi ikan demersal terbesar berada dikedalaman yang dangkal, dikarenakan masih dipengaruhi masukan nutrien atau unsur hara dari daratan.

\subsection{Verifikasi Hasil Tangkapan Nela- yan Pelabuhan Pangkajene terha- dap Data Akustik}

Distribusi ikan demersal di Perairan Pangkajene yang ditemukan pada kedalaman $10.45 \mathrm{~m}$ sampai $15.25 \mathrm{~m}$ memiliki nilai Sv ikan yang tinggi, sebagai ikan kakap dan jenaha (Lutjanidae) serta kerapu dan sunu (Serranidae). Berdasarkan hasil tangkapan nelayan di Pelabuhan Pangkajene pada bulan Oktober 2011 dengan jumlah total hasil tangkapan sebesar 1,259 Kg (Gambar 7), diperoleh famili Lutjanidae (kakap dan jenaha) merupakan ikan yang paling banyak tertangkap yaitu sebesar 69.24 $\%$, diikuti oleh famili Serranidae (kerapu dan sunu) tertangkap sebanyak 30.69\%, sedangkan species Lethrinus spp. (lencam) dan Plecthorinchus spp. (kaneke) tertangkap paling sedikit kurang dari $1 \%$.

Hal ini didukung pernyataan Melianawati dan Aryati (2012) bahwa ikan kakap (Lutjanus) merupakan ikan yang memiliki habitat luas. Ikan ini dapat hidup di perairan tropis dan subtropis, pada kedalaman sekitar $100 \mathrm{~m}$ dengan habitat terumbu karang dan juga dasar perairan berpasir. Hadisubroto dan Djamal (1992) menjelaskan bahwa jenis ikan kerapu habitat hidupnya di daerah karang bergerak tidak begitu jauh dari habitatnya, dapat dijumpai di bawah karang-karang batu (karang massive) atau pada dasar perairan yang banyak ditumbuhi akar bahar (Gorgonian). Ikan kerapu banyak tertangkap di lokasi kapal tenggelam atau pada perairan dengan kedalaman sekitar 45 $\mathrm{m}$.

\subsection{Hubungan Sv Ikan terhadap \\ Kedalaman dan E1}

Korelasi antara tipe substrat terhadap distribusi ikan demersal (E1, Depth, dan Sv ikan) dapat dianalisis dengan menggunakan analisis komponen utama (AKU). Hubungan antara Sv ikan terhadap tipe substrat (E1) dan hubungan antara Sv ikan terhadap kedalaman perairan (depth) tidak berpengaruh nyata secara positif dilihat dari nilai matriks korelasi untuk kedua hubungan yakni 0.26 dan 0.31 (Tabel 4). Legendre (1983) dalam Allo (2008) menyatakan bahwa matriks korelasi menjelaskan hubungan antar parameter yang ada. Suatu korelasi dinyatakan berhubungan positif atau berbanding lurus jika nilainya 0.50 sampai 1.00 , berhubungan negatif atau berbanding terbalik jika nilainya -0.50 sampai -1.00 dan jika nilainya diantara -0.50 sampai 0.50 tidak mempunyai pengaruh nyata baik positif ataupun negatif.

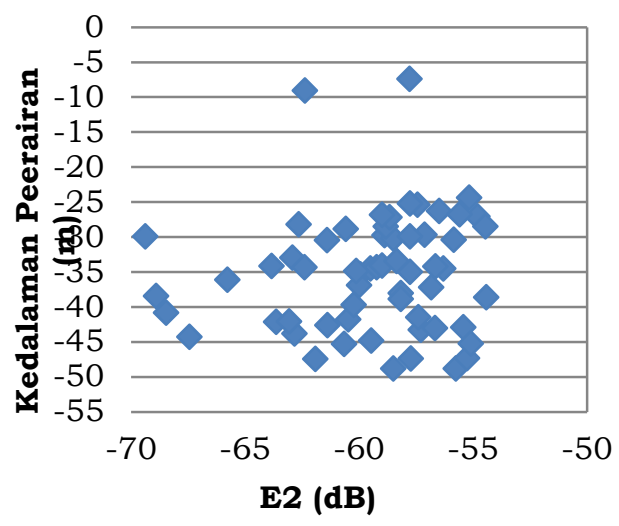

a.

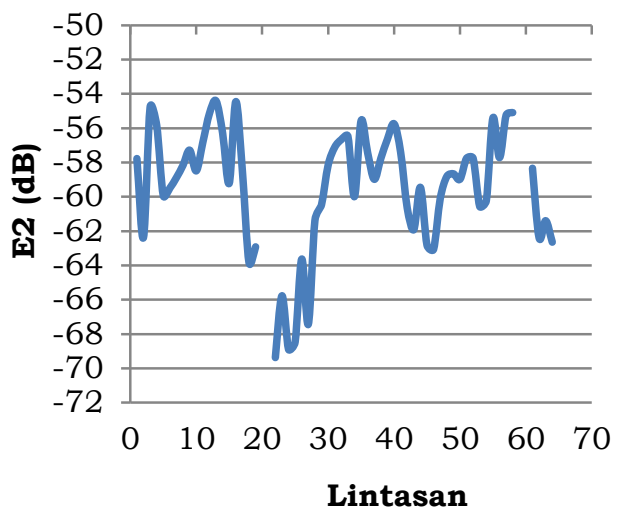

b.

Gambar 3. a. Sebaran vertikal E2; b. Sebaran horizontal E2 
Korelasi antara parameter juga dapat dilihat dari kedekatan garis parameter tersebut. Gambar 8 menunjukkan Sv ikan memiliki kedekatan hubungan dengan kedalaman perairan (depth), hal ini dikarenakan kedekatan garis antara kedua parameter tersebut yang berada pada sumbu negatif faktor 2 . Sv ikan dengan E1 memiliki nilai korelasi yang rendah, hal ini dapat dilihat dari kedekatan antara kedua garis yang berada pada sumbu positif (E1) dan sumbu negatif (Sv Ikan) faktor 2. E1 cenderung memilki kedekatan hubungan yang kuat dengan E2, hal ini dikarenakan kedekatan garis atara kedua parameter berada pada sumbu positif faktor 2 .

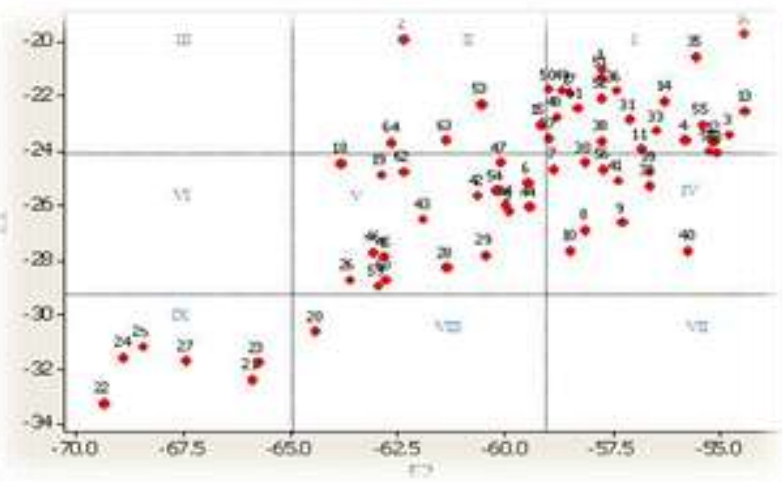

Gambar 4. Klasifikasi tipe substrat berdasarkan nilai E2 dan E1

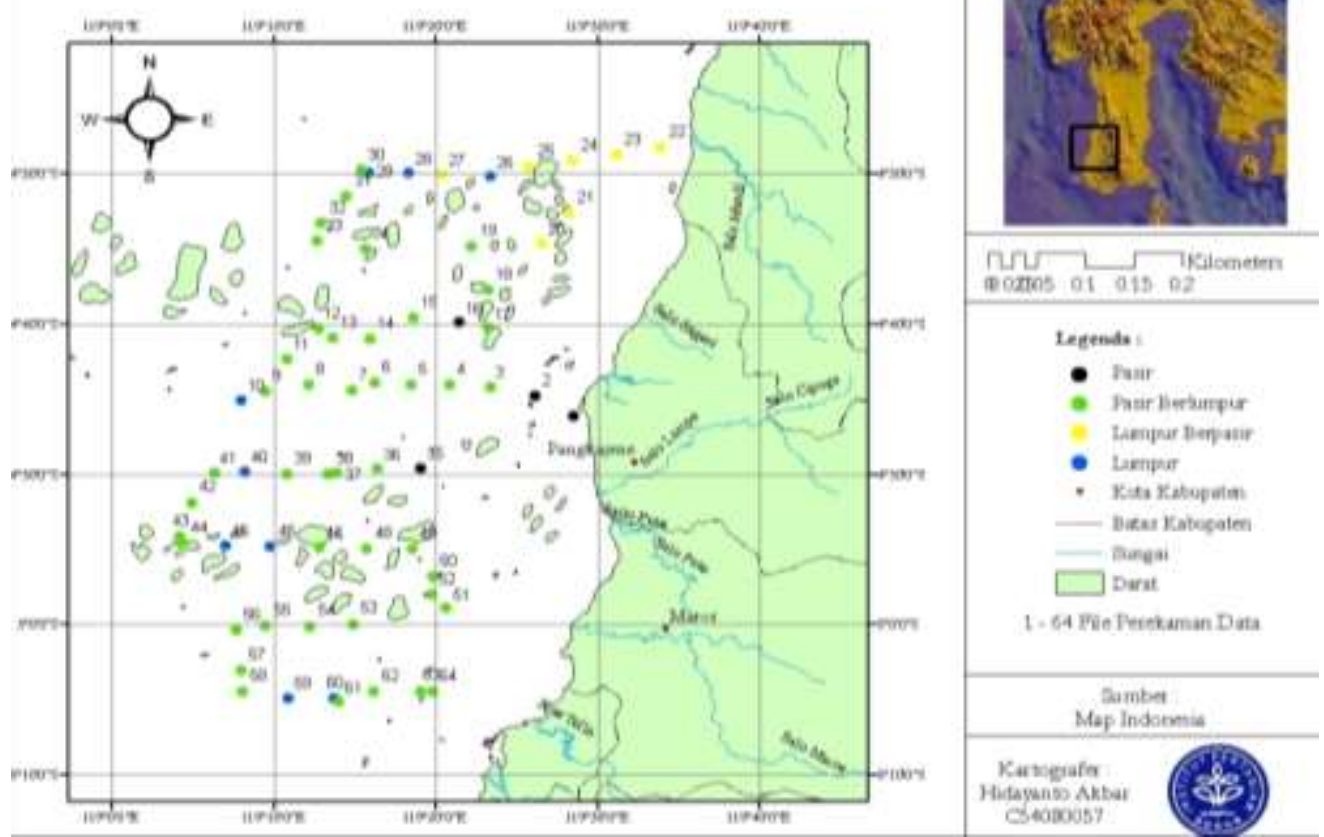

Gambar 5. Sebaran tipe substrat di lokasi penelitian 


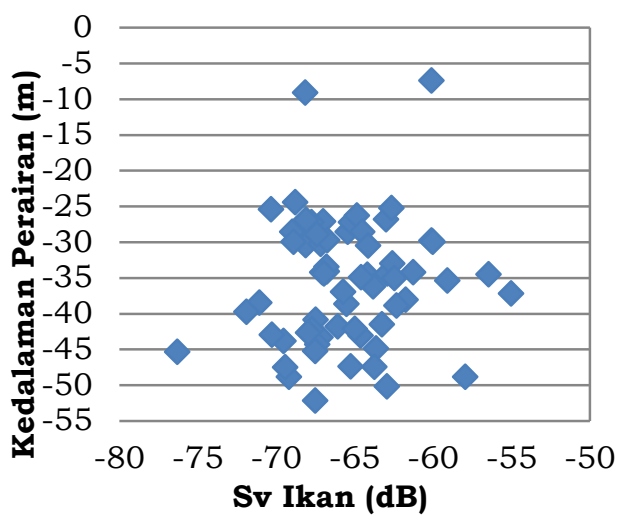

a.

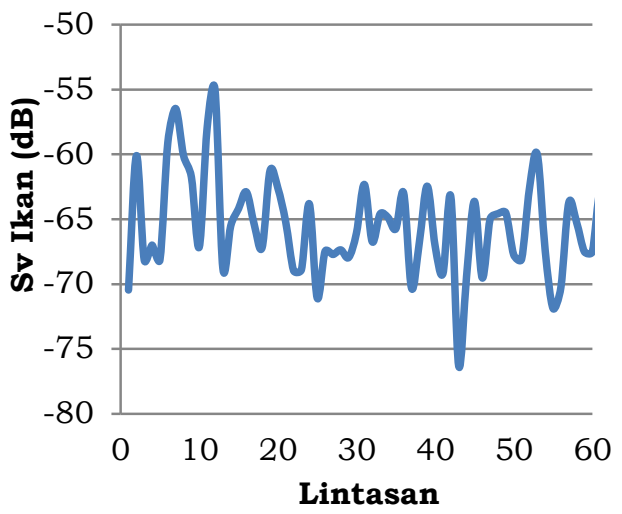

b.

Gambar 6. a. Sebaran vertikal Sv Ikan; b. Sebaran horizontal Sv Ikan

Tabel 3. Rata-rata Sv ikan pada selang kelas kedalaman dan tipe substrat

\begin{tabular}{|c|c|c|}
\hline Selang Kelas Kedalaman (meter) & Sv Ikan (dB) & Tipe Substrat \\
\hline $5.65-10.45$ & -62.29 & Pasir \\
\hline $10.45-15.25$ & -55.65 & $\begin{array}{l}\text { berlumpur } \\
\text { Pasir }\end{array}$ \\
\hline $15.25-20.05$ & -56.56 & $\begin{array}{l}\text { berlumpur } \\
\text { Pasir }\end{array}$ \\
\hline $20.05-24.48$ & -59.24 & $\begin{array}{l}\text { berlumpur } \\
\text { Pasir }\end{array}$ \\
\hline $24.48-29.65$ & -63.12 & $\begin{array}{l}\text { berlumpur } \\
\text { Pasir }\end{array}$ \\
\hline $29.65-34.45$ & -63.16 & $\begin{array}{l}\text { berlumpur } \\
\text { Pasir }\end{array}$ \\
\hline $34.45-39.25$ & -64.51 & $\begin{array}{l}\text { berlumpur } \\
\text { Pasir }\end{array}$ \\
\hline $39.25-44.05$ & -67.93 & $\begin{array}{l}\text { berlumpur } \\
\text { Pasir }\end{array}$ \\
\hline $44.05-48.85$ & -66.33 & $\begin{array}{l}\text { berlumpur } \\
\text { Lumpur }\end{array}$ \\
\hline $48.85-53.65$ & -67.95 & $\begin{array}{l}\text { berpasir } \\
\text { Lumpur }\end{array}$ \\
\hline $53.65-58.45$ & -65.29 & berpasir \\
\hline
\end{tabular}

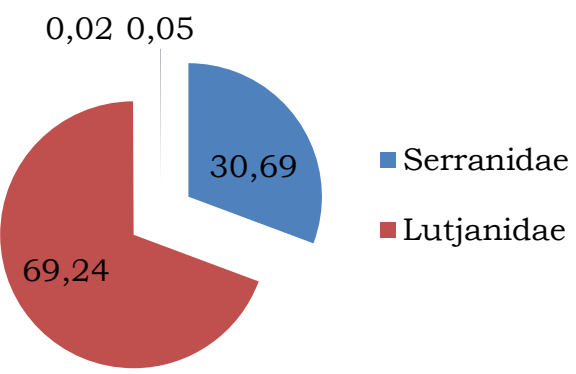

Gambar 7. Persentase hasil tangkapan nelayan di Pelabuhan Pangkajene Oktober 2011 
Tabel 4. Korelasi antar parameter

\begin{tabular}{lllll}
\hline Variable & Sv Ikan & E1 & Depth & E2 \\
\hline Sv Ikan & 1 & 0.259 & 0.305 & 0.198 \\
E1 & 0.259 & 1 & 0.571 & 0.710 \\
Depth & 0.305 & 0.571 & 1 & 0.091 \\
E2 & 0.198 & 0.710 & 0.091 & 1 \\
\hline
\end{tabular}

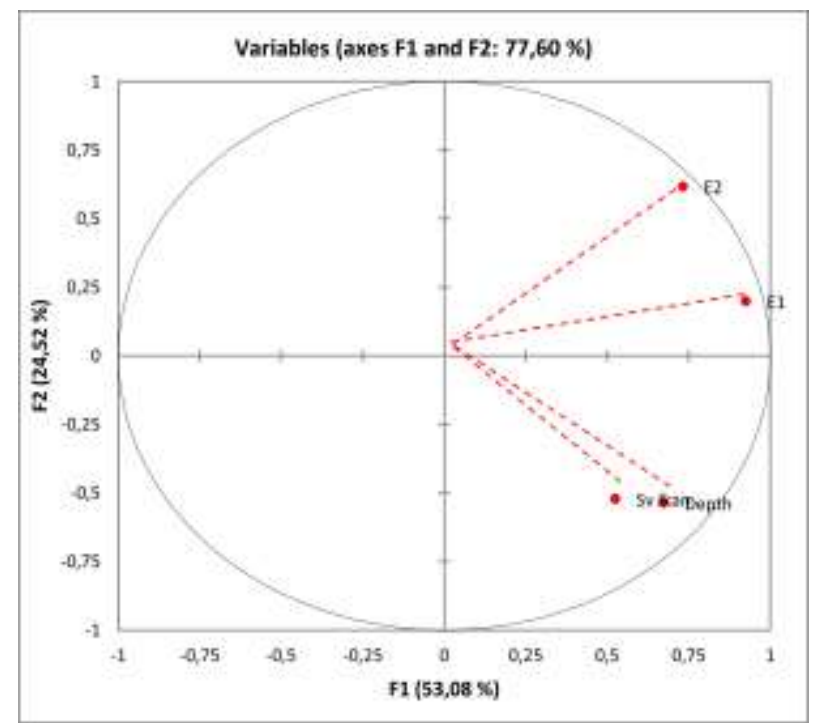

Gambar 8. Grafik kedekatan antar parameter

\section{KESIMPULAN}

Perairan Pangkajene memiliki kedalaman yang dangkal dengan rata-rata kedalaman $35.02 \mathrm{~m}$. Bertambahnya kedalaman substrat akan berubah dari kasar hingga halus (E1) dan dari keras hingga lunak (E2). Distribusi ikan demersal terbesar berada di kedalaman $10.45 \mathrm{~m}$ sampai $15.25 \mathrm{~m}$, menyukai tipe substrat pasir berlumpur, misalnya ikan kakap dan jenaha (Lutjanidae). Kedalaman perairan (depth) lebih mempengaruhi distribusi ikan demersal (Sv ikan) dibandingkan tipe substrat (E1), ditunjukkan dengan nilai korelasi antara depth.

\section{DAFTAR PUSTAKA}

Allo O. A. T. 2008. Klasifikasi Habitat Dasar Perairan dengan Menggunakan instrumen hidroakustik SIMRAD EY60 di Perairan Sumur, Pandeglang - Banten. [skripsi]. Bogor. Institut Pertanian Bogor. 100 hlm.
Burdah R. 2008. Pengukuran Densitas Ikan Menggunakan Sistem Akustik Bim Terbagi (Split Beam) di Laut Jawa pada Bulan Mei 2006. [skripsi]. Bogor. Institut Pertanian Bogor. $95 \mathrm{hlm}$.

Hadisubroto I. dan Djamal R. 1992. Usaha Perikanan Pancing Tangan (Kakap Merah dan kerapu) di Desa Sungai Teluk-Bawean. Jurnal Penelitian Perikanan Laut. (68):37-47.

Melianawati R. dan Aryati R. W. 2012. Budidaya Ikan kakap Merah (Lutjanus sebae). Jurnal Ilmu dan Teknologi Kelautan Tropis. 4(1):80-88.

Nugraheni A. D. 2011. Hubungan antara Distribusi Ikan Demersal, Makrozoobentos, dan Substrat di Perairan Malaka. [skripsi]. Bogor. Institut Pertanian Bogor. 67 hlm.

Pujiyati S. 2008. Pendekatan Metode Hidroakustik Untuk Analisis Keterkaitan Antara Tipe Substrat Dasar Perairan Dengan Komunitas Ikan Demersal. [disertasi]. Sekolah Pasca Sarjana. Bogor. Institut Pertanian Bogor. 185 hlm. 
Siswanto, A. Y. 2008. Sebaran Nilai Target Strength dan Densitas Ikan Demersal di Perairan Laut Jawa $\left(108^{\circ}-106^{\circ} \mathrm{BT}\right)$ pada Bulan Mei. [skripsi]. Bogor. Institut Pertanian Bogor. 81 hlm. 